IRA-International Journal of Education \&

Multidisciplinary Studies

ISSN 2455-2526; Vol.03, Issue 03 (2016)

Institute of Research Advances

http://research-advances.org/index.php/IJEMS

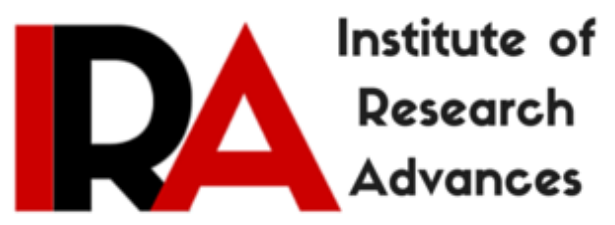

\title{
Skill Development Landscape in India
}

\author{
Mrs. Smita Dayal \\ Research Scholar, \\ K. J. Somaiya Institute of Management Studies and Research, \\ Mumbai, India.
}

DOI: http://dx.doi.org/10.21013/jems.v3.n3.p24

\section{How to cite this paper:}

Dayal, S. (2016). Skill Development Landscape in India. IRA International Journal of Education and Multidisciplinary Studies (ISSN 2455-2526), 3(3). doi:http://dx.doi.org/10.21013/jems.v3.n3.p24

(C) Institute of Research Advances

\section{(cc) BY-NC}

This works is licensed under a Creative Commons Attribution-Non Commercial 4.0 International License subject to proper citation to the publication source of the work.

Disclaimer: The scholarly papers as reviewed and published by the Institute of Research Advances (IRA) are the views and opinions of their respective authors and are not the views or opinions of the IRA. The IRA disclaims of any harm or loss caused due to the published content to any party. 


\begin{abstract}
The confluence of technological advancement, globalisation and economic liberalisation in the recent years has prompted governments in developed and developing countries alike to prioritise skills development as a key strategy for economic competitiveness and growth. India has the youngest and one of the largest pools of "demographic dividend" that needs to be nurtured, and through appropriate skill development it can foster economic growth, equitable wealth generation as well as meet the global skill shortages. The large population, majority of which are either unemployed or underemployed in the unorganized sector, need to be given adequate skill training which will not only aid the industries but will also encourage entrepreneurial ventures that will in turn generate future employment opportunities and fuel economic growth. This paper is an attempt to understand the existing skill development landscape in India by having a birds's eye view of the importance of skill development for the economy, skill related statistics, institutional framework in skill development, skill development initiatives running in the country currently, major challenges, policy framework and the road head for meeting the Government's aim to train 500 million people by 2022 by empowering all individuals through improved skills, knowledge and nationally and internationally recognised qualifications to gain access to decent employment and ensure India's competitiveness in the global market. It is observed that in order to make the skill development mission a success, it is important for the Government to focus on inclusive measures, quality in delivery, use of information and communication technology to meet scalabity and speed of delivery, introduction of modular and short term programs to meet industry specific needs etc. The cooperative federation and the involvement of States will further boost the skill development ecosystem in India.
\end{abstract}

Key words: Knowledge economy, inclusive growth, modular employable skills

\title{
Introduction
}

Skills and knowledge are the driving forces of economic growth and social development for any country. India is expected to be home to a skilled workforce of 500 million by 2022. About 12 million persons are expected to join the workforce every year. This talent pool needs to be adequately skilled. It is thus estimated that the required capacity for training the new workforce as well as portion of the existing workforce would be about 15 million annually.

As India moves progressively towards becoming a 'knowledge economy' it becomes increasingly important that the country should focus on advancement of skills and these skills have to be relevant to the emerging economic environment. In order to achieve the twin targets of economic growth and inclusive development, India's Gross Domestic Product (GDP) has to grow consistently at $8 \%$ to $9 \%$ per annum. This requires significant progress in several areas, including infrastructure development, agricultural growth coupled with productivity improvements, financial sector growth, a healthy business environment, ably supported by a skilled workforce. Assuming that the average growth rate of the agricultural sector is around $4 \%$, the secondary as well as the tertiary sector have to perform way above $10-11 \%$ to pull up the economic growth to reach the desired average. In such a scenario, it is obvious that a large portion of the workforce would migrate from the primary sector (agriculture) to the secondary and tertiary sectors. However, the skill sets that are required in the manufacturing and service sectors are quite different from those in the agriculture sector. This creates a huge skill gap when 
migration occurs at the micro level from the agriculture sector to the secondary and tertiary sector that is quite evident in the country. This scenario necessitates skill development initiatives in the workforce in India.

Out of the current workforce of about 450 million, only about 8\%-9\% are engaged in the organized/formal sector. In India, only about $5 \%$ of the workforce has marketable skills, as compared to $50 \%$ to $60 \%$ in other countries. The magnitude of the challenge is further evident from the fact that about 12 million persons are expected to join the workforce every year. This emerging socio-economic scenario is poised to drive the demand for skilling India.

Various steps are being taken towards meeting the above objectives, such as, the formulation of the National Skills Development Policy, delivery of Modular Employable Schemes, upgradation of existing institutions through World Bank and Government of India funding, as well as upgradation of training institutes under Public Private Partnership mode, setting up of the National Skill Development Corporation, and the plan to establish 50,000 Skill Development Centres. Apart from these, several ministries/departments and state governments are engaged in skill development initiatives.

\section{Rationale for prioritizing Skill development}

1) The skills possessed by each country's population provide the fundamental determinants of prosperity and well-being and hence requires utmost priority.

2) India is ranked at 135 out of 187 countries on the Human Development Index in 2013 and the improvement in ranking has just been one place from 2008. Hence there is a need to focus on skill development to foster human development.

3) Skill building can be viewed as an instrument to improve the effectiveness and contribution of labor to the overall production.It is as an important ingredient to push the production possibility frontier outward and to take growth rate of the economy to a higher trajectory.

4) The global financial crisis has crunched the employment opportunities. It is thus an instrument to empower the individual and improve his/her social acceptance or value.

5) The global economy is expected to witness a skilled man power shortage to the extent of around 56 million by 2020, according to the ILO report. Thus, Indian "demographic dividend" of the youngest population in the world needs to be exploited to meet the skilled manpower requirements in India and abroad.

6) The confluence of technological advancement, globalisation and economic liberalisation in recent years has prompted governments in developed and developing countries alike to prioritise skills development as a key strategy for economic competitiveness and growth.

7) It is important to meet the Inclusive Growth Initiatives as well as Equitable Distribution of Wealth and Opportunity under the Welfare State concept.

8) Developing countries are deficient in skills relative to richer countries, significant numbers of those who are educated and trained end up unemployed, working in jobs that under-utilise their skills or immigrating to other countries resulting in Brain Drain. The result is a misallocation and waste of resources that the countries can ill afford. India needs to focus more explicitly on the link between investments in skills development and employment and productivity. 
9) Reflecting an international consensus on the critical role of skills for economic advancement, including in the poorest countries, the G20 leaders included human resource development as one of nine pillars in the group's Multi-Year Action Plan on Development adopted at its Seoul Summit in November 2010. For the HRD pillar, the G20 Action Plan envisages two actions: (1) create internationally comparable skills indicators; and (2) enhance national employable skills strategies.

10) The percentage of workers (both regular and others) in the formal sector is about 13.69 per cent of the labour force. Due to a greater percentage of workers in the informal sector there remains a huge variation in wages. Low levels of income force people to remain 'employed' even if wage earnings, or in the case of selfemployment, imputed wage earnings fall. In this situation, focusing on the measured rate of employment has little economic significance since many people who are technically employed may be under considerable economic stress.

\section{Skill related Statistics in India}

\section{Employment:}

1. Percentage distribution of persons available for $\mathbf{1 2}$ months according to the duration of their work.

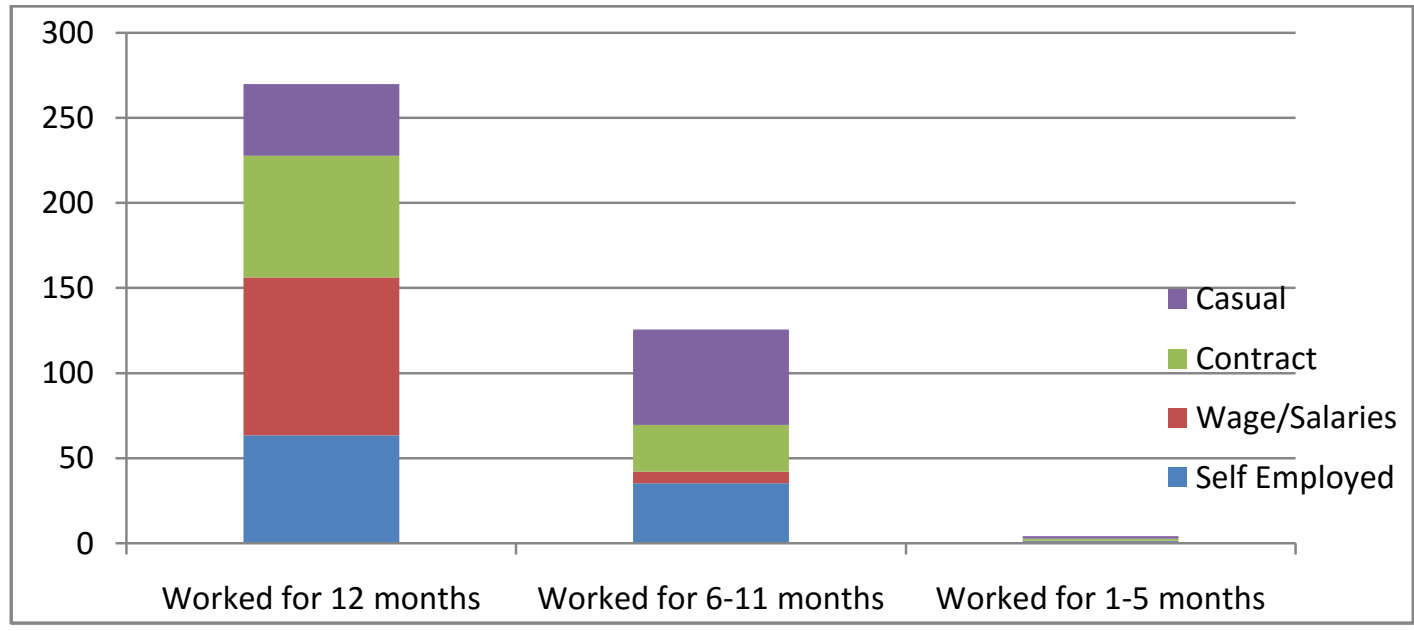

Source: Ministry of Labour and Employment Labour Bureau 
2. Share of Formal and Informal employees across organized and organized sectors in 2011-12 (in \%)

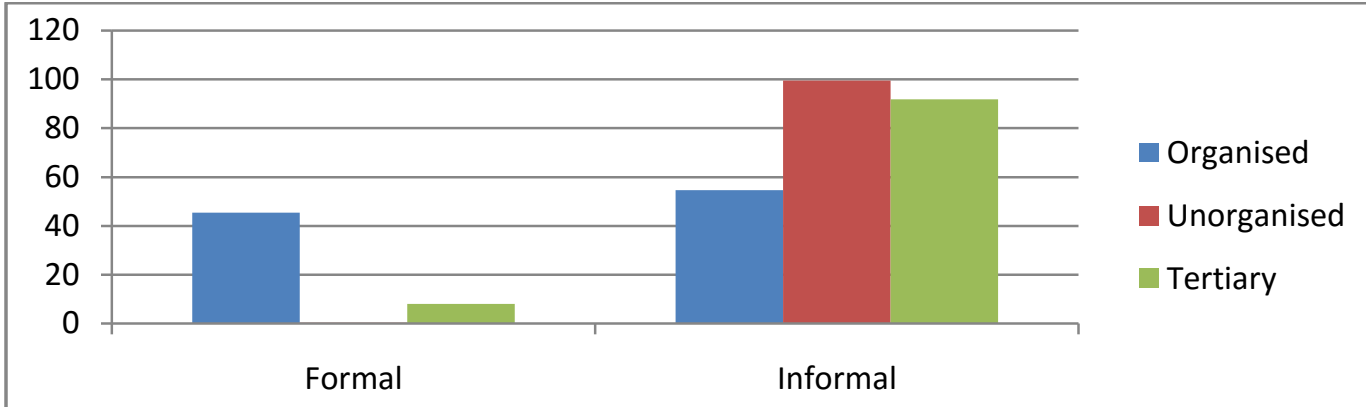

Source: NitiAayog

3. Projected Employment in Agriculture, Industry, and Services Year GDP growth rate Projected Employment (in millions)

\begin{tabular}{|l|l|l|l|l|l|}
\hline Year & $\begin{array}{l}\text { GDP Growth } \\
\text { Rate }\end{array}$ & $\begin{array}{l}\text { Projected } \\
\text { Employment } \\
\text { in million) }\end{array}$ & & & \\
\hline & & Agriculture & Industry & Services & Total \\
\hline $\mathbf{2 0 1 1 - 1 2}$ & $9 \%$ & 229.2 & 105 & 153.5 & 487.7 \\
\hline & $7 \%$ & 225.4 & 102 & 149 & 476.4 \\
\hline & $5 \%$ & 221.5 & 99.1 & 144.6 & 465.2 \\
\hline $\mathbf{2 0 1 6 - 1 7}$ & $9 \%$ & 240.2 & 126.2 & 189.5 & 555.9 \\
\hline & $7 \%$ & 232 & 116.8 & 174.8 & 523.5 \\
\hline & $5 \%$ & 224 & 108.1 & 161.2 & 493.3 \\
\hline
\end{tabular}

Source: 'The Challenge of Employment in India - An Informal Economy Perspective' (April, 2009) 
Education:

4. Current Education and skill development Capacity in India.

\begin{tabular}{|l|l|l|}
\hline Category & Sub-Category & $\begin{array}{l}\text { No of such } \\
\text { Institutions }\end{array}$ \\
\hline School Education & Pre-Primary Schools & 67157 \\
\hline & Primary Schools & 772568 \\
\hline & Middle Schools & 288493 \\
\hline $\begin{array}{l}\text { Vocational } \\
\text { Training }\end{array}$ & Higher and Higher Secondary & 159708 \\
\hline & Governtment ITI & 2076 \\
\hline College Education & Private ITC & 5529 \\
\hline & Central University & 20 \\
\hline & State University & 216 \\
\hline & Deemed University & 101 \\
\hline & Institutions of National Importance & 13 \\
\hline & Research Institutions & 140 \\
\hline $\begin{array}{l}\text { Technical } \\
\text { Proffessional }\end{array}$ & and & 11,698 \\
\hline \multirow{2}{*}{ Education } & Engg., Tech., \& Arch., Colleges & 1562 \\
\hline & $\begin{array}{l}\text { Medical Colleges (Allo/ Ayur/ Homeo/ Unani/ } \\
\text { Nurs./ Pharm., etc.) }\end{array}$ & 2,053 \\
\hline & Teacher Training Colleges & 1,669 \\
\hline & Polytechnics & 1,274 \\
\hline & $\begin{array}{l}\text { Others (Includes Law, Management, MCA/IT, } \\
\text { Agriculture etc.) }\end{array}$ & 2,513 \\
\hline & & \\
\hline & & \\
\hline
\end{tabular}

Source: Select Educational Statistics 2005-06, Annual Report 2009-10 of Ministry of Labour and Employment

\section{Category Sub-Category Enrolment}

\section{School Education}

Pre-Primary Students

Primary (Class I - V)

$132,048,727$

Secondary (Class VI - VIII)

$52,195,171$

High School (Class IX - X)

$24,971,520$

Higher Secondary (Class XI - XII)

$13,414,499$

Sub-Total

$227,893,970$

\section{Vocational Training}

Vocational Training - ITI/ITC

$1,062,524$

\section{Higher Education}

Ph. D / D. Sc/ D. Phil

36,019

MA

481,521

$\mathrm{MSc}$ 
MCom

BA/BA (Hons).

B.Sc.

B.Com

BE/ B Arch

Medicine, Dentistry, Nursing, etc.

B.Ed

Enrolment in Open Universities

Polytechnic Institutes

Others

Sub-Total
156,714

$3,727,727$

$1,579,355$

$1,455,457$

$1,668,228$

305,629

244,825

773,917

690,410

$2,973,517$

$14,323,566$

Source: Select Educational Statistics 2005-06, Annual Report 2009-10 of Ministry of Labour and Employment

\section{Vocational Training:}

1. Distribution of persons aged 15 years and above who received vocational training (in \%)

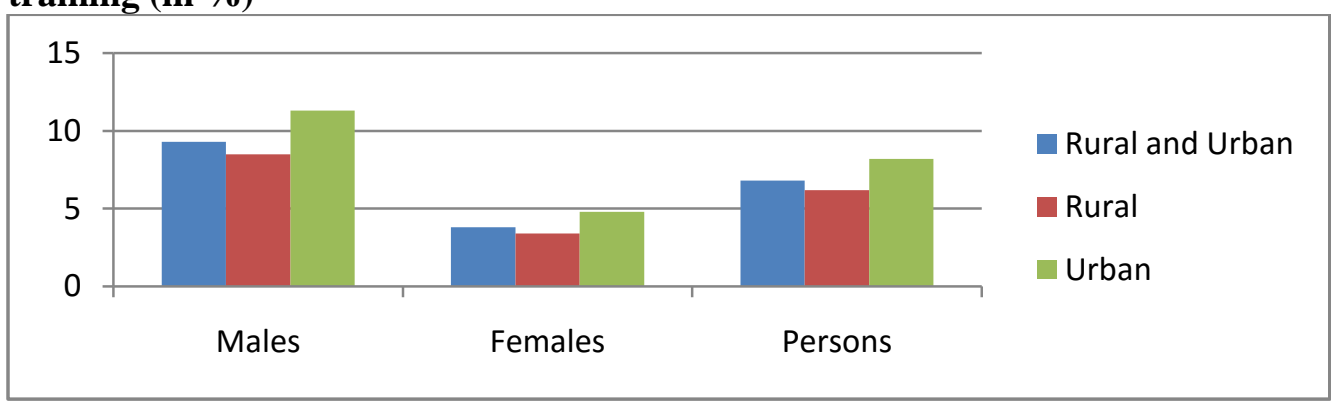

Source: Ministry of Labour and Employment Labour Bureau

2. Distribution of persons aged 15 years and above who received/receiving vocational training by broad activity status (in \%).

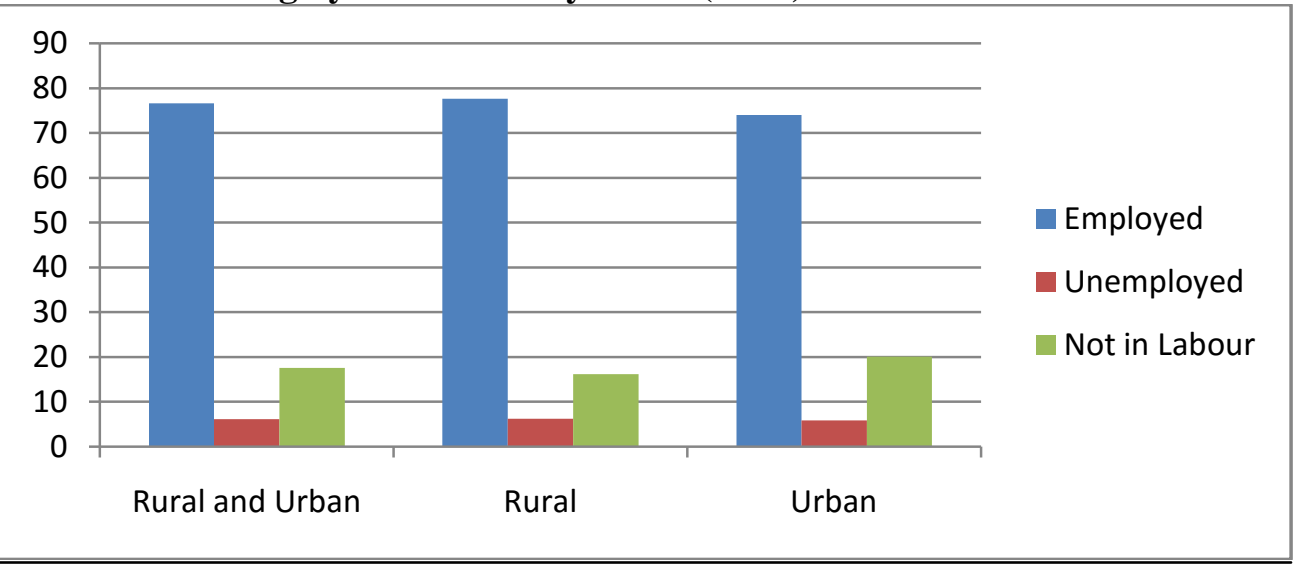

Source: Ministry of Labour and Employment Labour Bureau 
3. Distribution of persons aged 15 years and by type of vocational training (in \%)
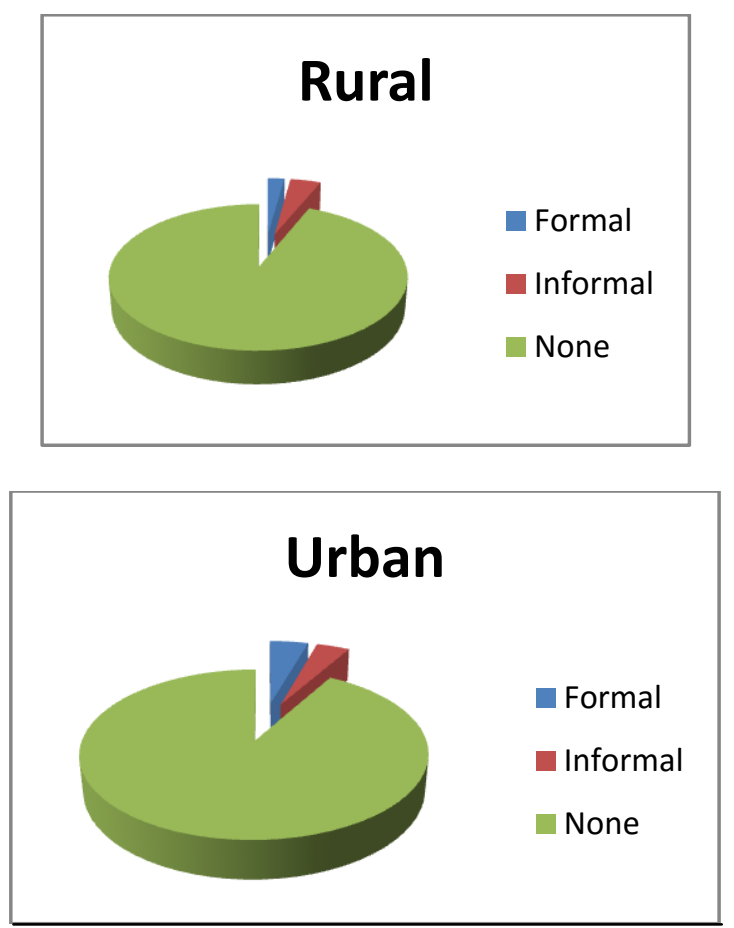

4. Distribution for persons aged 15 years \& above by main activity \& educational classification (in \%).

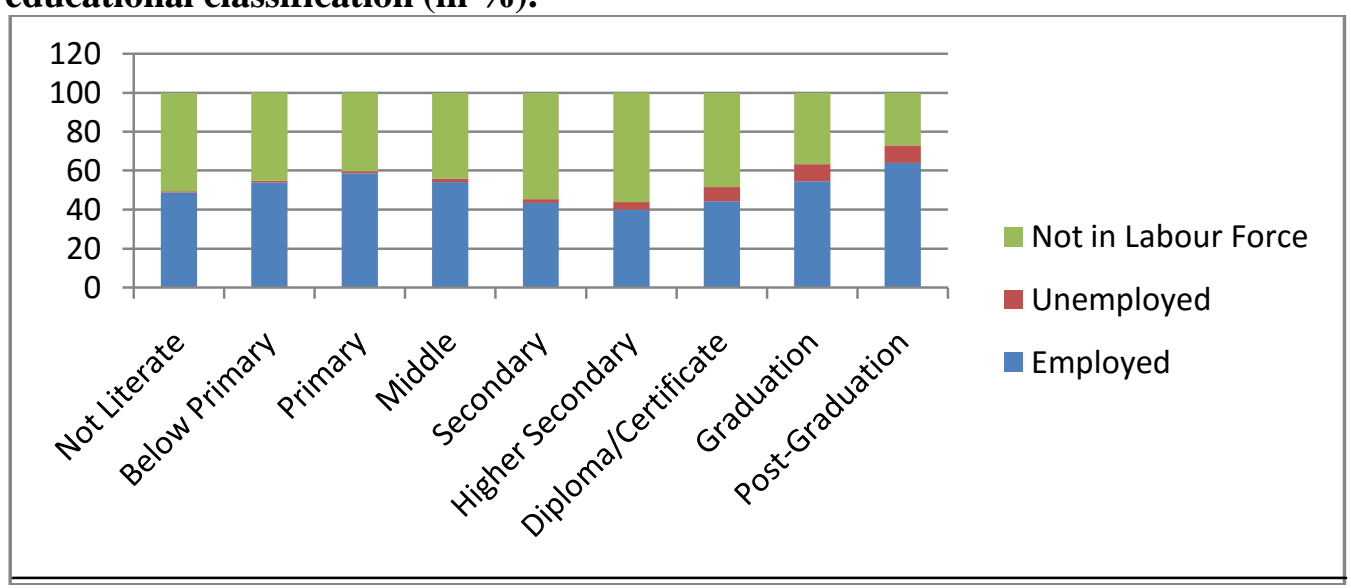

Source: Ministry of Labour and Employment Labour Bureau

The current size of India's formally skilled workforce is small, with approximately 2 percent. Furthermore, the number is even lower than that of smaller countries, South Korea and Japan, which have 96 and 80 per cent respectively. Limited participation of the private sector has been one of the major reasons for the marginal size of the formally skilled workforce. The poor skill levels among India's workforce are attributed to dearth of a formal vocational education framework, with wide variation in quality, High school 
dropout rates, Inadequate skills training capacity and negative perception towards skilling and lack of "industry-ready" skills, even in professional courses(Ernst \& Young LLP and FICCI, 2013).

\section{Skill Development Ecosystem in India}

The current structural framework of education and skill development in India:

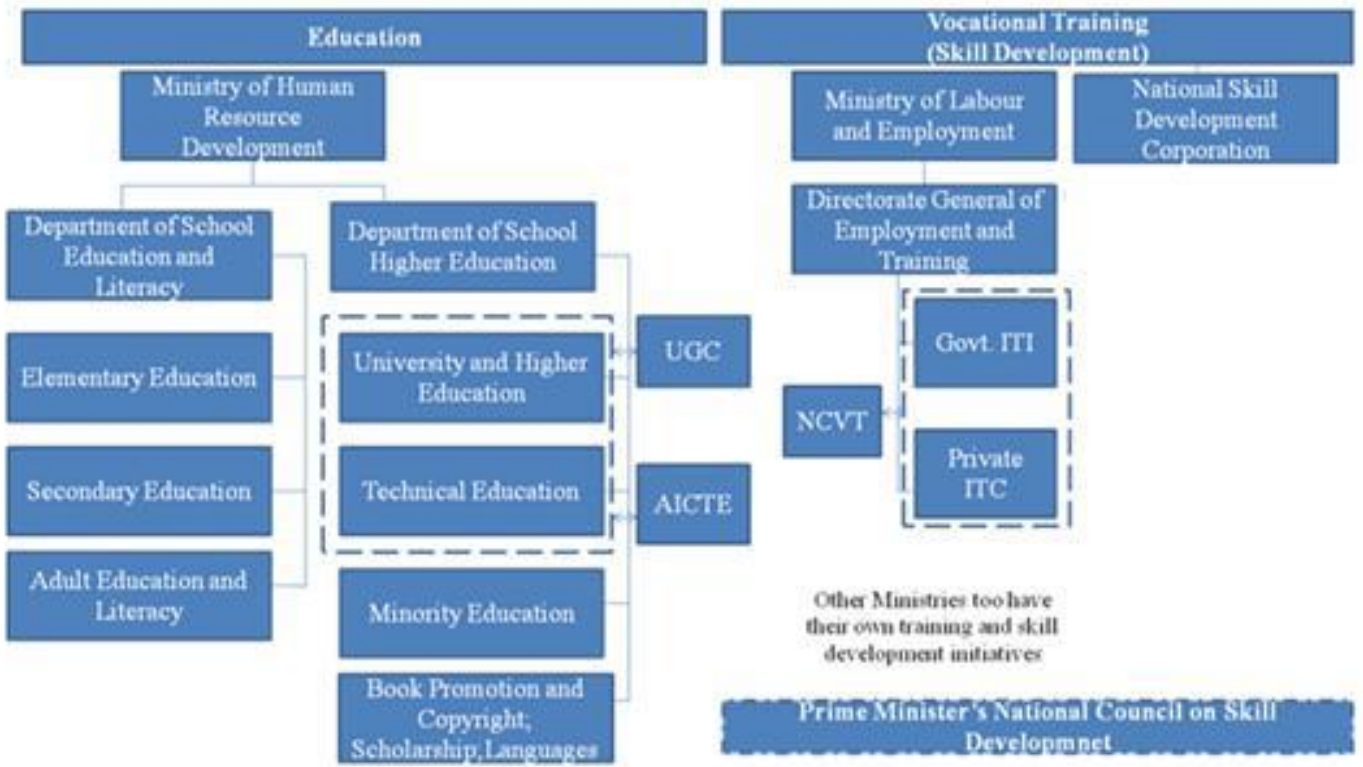

Source: FICCI report

Education including all aspects of higher education and college education fall under the purview of Ministry of Human Recourse Development. The University Grants Commission (UGC) provides funds in the form of grants and also coordinates as well as sets standards for teaching, examination and research in universities.

Engineering education, polytechnics etc. fall under the category of technical education. AICTE is the regulatory body for Technical education in India.

A large part of the current vocational training infrastructure, the Government Industrial Training Institutes (ITIs) and Private ITIs, falls under the Ministry of Labour and Employment's Directorate General of Employment and Training (DGET).

The National Council on Vocation Training (NCVT) plays a key role in the formation of training curriculum, policies, standards, as well as in certification by means of the 'trade test'.

A three-tier institutional structure consisting of: (i) the Prime Minister's National Council on Skill Development, (ii) the National Skill Development Coordination Board, and (iii) the National Skill Development Corporation, has been set up to take forward the Skill Development Mission. 


\section{PRIME MINISTER'S NATIONAL COUNCIL ON SKILL DEVELOPMENT (NCSD)}

The Prime Minister's National Council on Skill Development was set up as an apex institution for policy advice, direction, and review. The Council is chaired by the Prime Minister with ministers for Human Resource Development, Finance, Heavy Industries, Rural Development, Housing and Urban Poverty Alleviation, and Labour and Employment as members. Deputy Chairman, Planning Commission, Chairperson of the National Manufacturing Competitiveness Council, Chairperson of the National Skill Development Corporation, and six experts in the area of skill development are its other members. The Prime Minister's National Council has endorsed a vision of creating 500 million skilled people by 2022 through skill systems, which must have high degree of inclusiveness in terms of gender, rural/urban, organized/unorganized, and traditional/contemporary. The Council will lay down the overall, broad policy objective, financing, and governance models and strategies relating to skill development, review the progress of the scheme and guide mid-course correction, including addition and closure of parts or whole of any particular programme or scheme, and coordinate public/private sector initiatives in a framework of collaborative action. The strategy to achieve such skill systems will depend upon innovative mechanisms for delivery through the Central Government, states, civil society, community leaders, and Public-Private Partnerships (PPPs).

\section{NATIONAL SKILL DEVELOPMENT COORDINATIONBOARD (NSDCB)}

The NSDCB has been set up under the Chairmanship of Deputy Chairman, Planning Commission, with secretaries of ministries of Human Resource Development, Labour and Employment, Rural Development, Housing and Urban Poverty Alleviation, and Finance as members. Secretaries of four states by rotation, for a period of two years, three distinguished academicians/subject area specialists are the other members. Secretary, Planning Commission is the member secretary of the board.

The Board is expected to enumerate strategies for implementing the decisions of the Prime Minister's National Council on Skill Development and develop appropriate operational guidelines and instructions for meeting the larger objectives of skill development.

A State Skill Development Mission (SSDM) is also expected to be established in each state.

The NSDCB decided to set up five subcommittees on:

(i) Reorientation of the curriculum for skill development on a continuous basis,

(ii) Evolving a vision on the status of vocational education and vocational training,

(iii) Re-modelling of apprenticeship training as another mode for on-the-job training,

(iv) Improving the accreditation and certification system, and

(v) Establishing an institutional mechanism for providing access to information on skill inventory and skill maps on a real time basis. All the five subcommittees have submitted their reports. The central ministries have also been urged to have the relative performance of existing schemes evaluated so 
that the government could rework on withdrawal of resources from nonperforming schemes so as to put them in the better performing schemes. It was suggested that such a prioritization exercise for all the schemes should be undertaken so that the skill development system underlining the paradigm shift could be financed. In this regard, the training capacity of key central ministries was reviewed. In addition, the status of the Skill Development

\section{NATIONAL SKILL DEVELOPMENT CORPORATION (NSDC)}

The third tier of the coordinated action on skill development is NSDC, which is a nonprofit company under the Companies Act with an appropriate governance structure. As mandated by the National Policy on Skill Development, NSDC will make periodic as well as annual reports of its plans and activities and put them in the public domain. The Corporation is expected to meet the expectations of the labour market, including the requirements of the unorganized sector. The Central Government has created a National Skill Development Fund with an initial corpus of Rs 995.10 crore for supporting the activities of the corporation. The corpus of the fund is expected to go up to about Rs 15,000 crore as it is intended to garner capital from governments, public and private sectors, and bilateral and multilateral sources. NSDC has been mandated to train about 150 million persons by 2022 under the National Skill Development Policy.

With a view to achieving this target, a detailed plan of action has been worked out indicating inter alia, the key focus areas, organization structure, and strategic interventions in critical sectors of the economy. Three major proposals, notably of the Gems and Jewellery Export Promotion Council, the Confederation of Indian Industry, and Self-Employed Women's Association (SEWA), which aim at providing skill training to about 23 lakh people by the end of eight years with a total outlay of about Rs 246 crore have been given 'in-principle' approval.

\section{$\underline{\text { National Policy on skill development }}$}

The Skill Development Policy provides an enabling environment and the Council and the NSDCB provide a mechanism for implementation at the highest level. The National Policy on Skill Development also provides a national policy response to guide the formulation of skill development strategies and coordinated action by all concerned by addressing the various challenges in skill development.'

National Policy on Skill Development, 2009 aims to train 500 million people by 2022 by empowering all individuals through improved skills, knowledge and nationally and internationally recognised qualifications to gain access to decent employment and ensure India's competitiveness in global market. It also aims to increase workforce in organised and unorganised sectors especially among youth, women, disables and disadvantage sections.

\section{Role of Employment Exchanges in Skill Development}

The role of Employment Exchanges is changing from being just repositories of lists of unemployed persons to taking up the role of District Career Guidance and Counseling Centres, in which capacity, the exchanges can play a crucial role in skill development. These exchanges are leveraging technology to increase their reach to the stakeholders. 
They are changing to provide guidance to individuals and mentoring aspiring individuals on entrepreneurship and self-employment. They are working in a PPP mode to effectively leverage the technology and process knowhow of private sector organizations.

\section{$\underline{\text { Private Sector role in Skill development }}$}

A majority of the skill development programs of various Central Ministries and State Missions are delivered by the private sector. For example Private organizations are adopting ITIs, leading and participating in their management boards and benchmarking the training courses and curriculums in these ITIs to be suitable for industry requirements. Skill development of this scale cannot beachieved without the participation from the private sector especially since a large percentage of skill demand is in this sector. The government realizes this and is engaging in a Public Private Partnership (PPP) mode where relevant to make this a success. NSDC is a body setup in the PPP mode to catalyze and increase the active participation of the private sector in skill development including the building of training capacity. Sector Skill Councils are setup with participation from industry bodies and private employers to standardize trade and competency definitions and as a part of the larger strategy to get employers to lead skill development efforts. Private training organizations, NGOs are being funded by NSDC to increase their training capacity. The Private sector is substantially incentivized to show interest and participate in skill development by qualifying the expenditure incurred by them as Corporate Social Responsibility initiatives and also exempting it from service tax let alone the various funding from the Government.

Role of Member of Parliament (MP)/Member of Legislative Assembly(MLA) in skill development

India is organized into 543 parliamentary constituencies and 4120 assembly constituencies. MPs and MLAs from these constituencies have the advantage of being most closely involved with these constituencies. Hence, they play an active role in bringing together relevant stakeholders (training providers, employers, NGOs, local people) and resources (local infrastructure, funds) and catalyze skill development in these constituencies.

\section{Role of Community Colleges}

Community colleges are aimed at supplementing mainstream education by providing alternate pathways to professional growth. Offerings could include vocational courses that enhance employability of students. MHRD announced the launch of 200 pilot colleges in 2012 after a series of events in 2011 built momentum for implementation of a more broad---based role for community colleges in the Indian system of higher education. This was unanimously endorsed in the State Education Ministers' Conference held on 22nd February 2012, and a Committee of 9 Education Ministers of States was constituted to finalize the concept and framework of the Community College scheme.

$\underline{\text { Role of Public sector units (PSUs) in skill development }}$

NSDA is engaged with PSUs to facilitate skill development in a variety of ways: 
1. Making available their spare/underutilized space and equipment for skill development.

2. Donating their obsolete equipment to training institutions to facilitate hands-on training.

3. Taking on a large number of trade apprentices so that these young men and women get real on-the-job training.

4. PSUs of each sector coming together to create at least one iconic national training centre for the training in skills needed for their sector. In a meeting of the PSUs, held on 3rd Sept, the oil and gas sector PSUs agreed to set up one such centre for training in the skills needed for the exploration, production, refining and marketing of petroleum products.

5. Encouraging that of all manpower engaged under their contracts, certain minimum percentages are skilled and certified.

6. Encouraging that $10 \%$ to $15 \%$ of their CSR funds are used exclusively for funding skill development training of individuals from each PSUs target area.

\section{$\underline{\text { World Class Skill Centre in Delhi }}$}

The World Class Skill Centre is a collaborative effort between the Delhi Government and Singapore Government to setup a 10,000 annual capacity training institution benchmarked to international standards. This center will have 50 faculty members trained in Singapore and a residential campus for 3000 students. This center will leverage the help of Ministry of Education, Singapore in curriculum design, teacher training, training pedagogy and some aspects of infrastructure creation. This center will contribute to establishing a new modern image for vocational education in the country.

\section{Skill development initiatives of the Government of India}

\section{$\underline{\text { Skill Development Initiative (SDI) Scheme }}$}

Government of India, Ministry of Labour\& Employment launched a Modular Employable Skills (MES) under Skill Development Initiative (SDI) Scheme through Directorate General of Employment \& Training in May 2007.Under this scheme, training to earlier school leavers and existing workers especially in an unorganised sector are to be trained for employable skills. In close consultation with industries/State Governments and expertise the scheme has been operationalized since 2007. A majority of Indian workforce does not possess marketable skills which is an impediment in getting decent employment and improving their economic condition. While India has large young population, only 5\% of the Indian labour force in the age group of 20-24 years has obtained vocational skills through formal means whereas the percentage in industrialized countries varies between $60 \%$ and $96 \%$. About $63 \%$ of the school students drop out at different stages before reaching Class X. Only about 2.5 million vocational training seats are available in the country whereas about 12.8 million persons enter the labour market every year. Even out of these training places, very few are available for early school dropouts. This signifies that a large number of school drop outs do not have access to skill development for improving their employability. The educational entry requirements and long duration of courses of the formal training system are some of the impediments for a person of low educational attainment to acquire skills for his livelihood. Further, the largest share of new jobs in India is likely to come from the unorganized sector that 
employs up to 93 per cent of the national workforce, but most of the training programs cater to the needs of the organized sector.

\section{Modular Employable Skills (MES)}

- MES was developed in close consultation with industry and micro enterprises in the unorganised sector, state governments, experts and academia. It offers flexibility in the provision of vocational training to those who have limited education and cannot afford to be away from employment for long periods of time. It also provides testing and certification of existing skills of a person as the SDI scheme provides a mechanism of third party assessment of trainees under the MES framework through DGET empanelled Assessment Bodies leading to NCVT certification that has national recognition in India.The SDI-MES scheme also has the objective of building capacity in the area of development of competency standards, course curricula, learning material and assessment standards in the country.

- The scheme is targeted towards the early school leavers and unorganised sector workers among others to increase their employability and skill level. The flexibility of training delivery has also proved beneficial to people who cannot devote a long time to studies. It was also considered to have improved industry participation through the assessing bodies which are empanelled throughout the country and involve employers at the grass roots level.

- The scheme has helped those who acquire training informally, due to certain socio-economic constraints, to be assessed and have their skills nationally recognised thus enhancing their employability.

- Working under the model of a public private partnership, the scheme has also helped private training institutions obtain accreditation for running vocational training programmes.

\section{$\underline{\text { Star Scheme }}$}

Thisscheme titled'TheNationalSkillCertificationandMonetaryRewardScheme' and popularly known as the Star Scheme was announced by the Finance minister in the budget speech in 2013 as a mode of encouragement to the rural youth to successfully complete the approved training program undertaken. A monetary reward of uptoRs 10,000 is awarded to selected candidates who have successfully completed their training program from an approved training institution. The scheme is targeted to benefit 10 lakh youth with a budgetary allocation of 1,000 crore rupees.

\section{National Urban Livelihood Mission/Swarna Jayanti ShahariRozgarYojna}

The schemed is aimed to provide gainful employment to unemployed and underemployed urban youth by encouraging skill development and self-employment. The scheme is targeted to employ 2 lakh urban poor under skill development.

\section{National Rural Livelihood Mission/Ajeevika}

The scheme is aimed at rural poor households to gain skill development and skilled wage employment opportunities. It encourages the below the poverty line rural households to 
convert into self-help groups and providing them training to set up their own micro enterprise.

\section{$\underline{\text { Jan ShikshanSansthan Scheme }}$}

The scheme has been launched under the National Literacy Mission, focusing on the poor, the illiterates, the neo-literates, the under-privileged and the un- reached. This scheme is unique in the hence it not only provides skill development but also links literacy and vocational skills to provide larger doses of Life Enrichment Education to people.

\section{Vocationalisation of Secondary Education Scheme}

It was launched by the HRD Ministry to strengthen vocational education in Classes XIXII.

\section{$\underline{\text { Saakshar Bharat Scheme }}$}

It is launched by the Department of School Education and Literacy, Ministry of Human Resource Development to promote and strengthen Adult Education, more so for women, by extending educational options to those adults who having lost the opportunity of access to formal education.

\section{$\underline{\text { Skill development for women and adolescent girls }}$}

Taking forward the no-discrimination policy when in comes to imparting skills, the Ministry of Women and Child Development has launched many schemes for the development and empowerment of women and children. Some of these include the Kishori Shakti Yojana, Rajiv Gandhi Scheme for Empowerment of Adolescent Girls (RGSEAG)-SABLA, Swayam Siddha and Support to Training and Empowerment Program for Women(STEP).

\section{Enhancing skill development Infrastructure in North- Eastern States and Sikkim}

The ministry of labour and employment has sanctioned the upgrade of 20 ITIs and to supplement the infrastructure deficiencies in 28 ITIs with an overall budget of 57.4 crores. It will indirectly aid in the social- economic development of the region.

\section{TheMulti-SectoralDevelopmentProgramme(MSDP)}

The Ministry of Minority Affairs has launched several schemes for skill development and enhancing employability of the minority segment. The ministry has earmarked atleast $10 \%$ of the funds for skill development.

The 'Learn and Earn 'scheme, also known as 'Seekho Aur Kamao', is a100\% Central Sector Scheme having the two components of placement linked skills training for modern trades and skills training program for traditional trades/arts/craftforms. 
The scheme 'Nai Roshni' for 'Leadership Development of Minority Women's specifically focuses on providing knowledge, tools and techniques to enable minority women to become self-reliant and independent.

\section{$\underline{\text { Skill development for people with disability }}$}

The Ministry for social justice and empowerment and various other state bodies have launched programs and schemes for providing them with vocational training courses. The National skill development council has supported Arunim, an NGO, to design and run programs and training sessions and to develop viable business models build around products made by people with disabilities.

\section{$\underline{\text { Rashtriya Kaushal Puraskar }}$}

NSDA proposes to launch the National Skill Awards (Rashtriya Kaushal Puraskar) to recognize outstanding achievements of individuals as well as institutional entities such as central ministries, State Skill Development Missions, Training Institutions, Public and Private Enterprises in the skill development space. This will help to create a positive and aspirational image around skill development.

\section{$\underline{\text { Rural Broadband Initiative }}$}

The Rural Broadband initiative of the Ministry of IT and Communications proposes to connect 250,000 panchayats in India using high capacity broadband connectivity of atleast $100 \mathrm{Mbps}$. Riding on this technology highway, skill centers can be established at panchayats and skilling content can be delivered digitally. Pilots for this are being planned in Vizag, North Tripura and Ajmer before a larger rollout.

\section{$\underline{\text { Citizen Service Centre Initiative }}$}

CSCs are the Citizen Service Centre's set up under the Ministry of IT \& Communications to provide prescribed citizen services including in the villages. These centres are being used both to deliver skill development through IT and also as centres for skill development.

\section{Impetus on Skill Development in the Budget 2015-16}

Both the Tenth and the Eleventh Plans noted the large gap between the number of new entrants to the labour force and inadequate availability of seats in vocational and professional training institutes. The Eleventh Plan also identified various sectors with prospects for high growth in output, and for generation of new employment opportunities. Accordingly, the Eleventh Plan aimed, inter alia, at launching a National Skill Development Mission which would bring about a paradigm change in handling 'Skill Development' programmes and initiatives.

1. A number of commendable steps have been initiated in the area of skill development, financial inclusion and social protection including pension and accident coverage for the unorganised sector.

2. 'Co-operative federalism' and empowerment of the States." In light of recommendations of the 14th Finance Commission to increase share of Central 
taxes from $32 \%$ to $42 \%$ to the States, the Finance Minister has done well by still maintaining the Plan Outlay for the Social Sector programs.

3. The Budget has a prominent thrust on facilitating 'access' and 'inclusion' in education as is evident from the proposed up-gradation of secondary schools and junior/middle schools and setting up of a student financial aid authority but is silent on quality aspects of education and facilitating PPPs in school education.

4. The vocational education and skill development has got a major fillip from the new 'Ministry of Skill Development and Entrepreneurship' and 'Make in India' initiative.

5. The proposed National Skill Mission would consolidate initiatives under various ministries and 31 Sector Skill Councils represented by industry players.

6. A number of initiatives like DeenDayalUpadhyayaGrameenKoushalyaYojana, NaiManzil, Skill India, NSDCs STAR2 and the Credit Guarantee Fund are expected to enhance access, equality, quality, innovation and institutional credit in the skill development area.

7. Commitment to girls' education through 'Betibachao, betipadhao' and 'SukanyaSamriddhi account' is a welcome measure.

\section{Challenges for skill development initiatives}

1) The enormous size of the task in building a system of adequate capacity

2) Ensuring equitable access to all, in particular the youth, disadvantaged groups, minorities, the poor, women, people with disabilities, dropouts, and those working in the unorganized sector

3) Reducing mismatch between supply and demand of skills

4) Diversifying skill development programmes to meet the changing requirements, particularly of the emerging knowledge economy

5) Ensuring quality and relevance of training

6) Building true market place competencies rather than mere qualifications

7) Creating effective linkages between school education and skill development

8) Providing mobility between education and training, different learning pathways to higher levels, and establishing a national qualifications framework

9) Providing opportunities for life-long learning for skill development

10) Promoting greater and active involvement of social partners and forging a strong, symbiotic, PPP in skill development

11) Establishing institutional arrangements for planning, quality assurance

12) Governance of a skill development system that promotes initiative, excellence, innovation, autonomy, and participation, while ensuring that the legitimate interests of all beneficiaries are protected

13) Strengthening the physical and intellectual resources available to the skill development system

14) Mobilizing adequate investments for financing skill development sustainably

Challenges on skill development that merit attention in the remaining years of the current Plan and the Twelfth Five Year Plan are presented below:

1) Government's preoccupation with providing and financing training has led to overlook its role in one key area- disseminating information about the availability and effectiveness of training programs. An important role that the Employment Exchanges, NCVT and the SCVTs could play is dissemination of information on 
the nature and quality of training particularly with respect to enrollment, institutional capacity, completion information and graduate follow-up data from all registered vocational institutions. This will enable the government and the stakeholders to see whether the system is responding to employers' needs and devise policies accordingly.

2) Whilst industry associations and individual employers are beginning to show interest involving themselves in the development and management of the ITIs, their involvement in the vocational training system is still at a nascent stage. Involvement of employers in management will see a major spurt only if the government is willing to provide institutions greater autonomy. However, increased autonomy needs to be accompanied by greater accountability and performance must be measured on the basis of internal/external efficiency indicators.

3) The management of the Vocational Education and Training System is fragmented and shared between various institutions, especially the NCVT, DGET and the SCVTs. There is a lot of scope to improve coordination between them and improve their effectiveness through more functional partnerships.

4) There is a need to identify institutions to carry out impact evaluation studies/ tracer studies/ surveys of graduates from vocational institutes on a regular basis.

5) Since funding is largely restricted to publicly provided training, little attention is paid to financing as an innovative means to encourage good quality public / private / in-service training. Once an institution begins to receive funding, subsequent funds are assured regardless of the institution's performance. Student fees in ITI's/polytechnics go to the State treasuries and hence, the training providers have very little financial incentive to improve efficiency and cater to the market requirements. Therefore, there is a need to re look at the funding of skill development activities.

\section{Future Implications}

- Labour Law Reforms

Though India has demonstrated remarkable resilience during the unprecedented global financial crisis and slowdown, its labour and employment sector faces several challenges, which need short-term as well as medium-term policy interventions at the level of the states as well as the Centre. Labour market policies are based on a large number of statutes enacted by the Central Government dealing with wages, social security, labourwelfare, occupational safety, and health besides industrial relations. There is a felt need for reforms in several of these labour laws with a view to imparting the much-needed labour market flexibility consistentwith the transformation of the Indian economysince these laws were enacted. Reforms in labourlaws would involve enabling provisions to increaseproduction, productivity, and expanding employmentopportunities while protecting the overall interestsof labour.

- Inclusive Growth

90 percent of the country's labour force in employed in the unorganized sector. In order to ensure inclusive growth there is a great need to focus on the skill development initiatives in the unorganized sector by organizing apprenticeship arrangements and funding proactive partnershipsbetween the government, the private sector, and NGOs through NSDC. Due to interdependence between the organized and unorganized sectors, labour productivity in the unorganized sector 
is crucial for the improvement of employment conditions in the unorganized sector.

- $\quad$ Skill Pro Government policy

The Government policies need to address the growth of jobless organized sector in order to reduce the disparity between labour and income, working conditions, social security etc. This requires developing and upgrading industry specific, technology specific skillset.

- Building skills infrastructure

In order to aid the youth acquire employment inemerging sectors, such as IT, biotechnology, nanotechnology,pharmaceuticals, alternative energy, and high-end construction and engineering,where opportunities are abundant and the wagesattractive, it is important toinstitutionalize more proactive industryinvolvement in key actions of training institutessuch as ITIs.Providing adequate resource focus and maintaining data of all the people involved in the skill development programs.There is also the overarching need for quality structures to be in place, especially from the perspective of successful implementation. There is also a need for deployment of funds for continuous upgradation of the existing infrastructure for incorporating latest technology and need based initiatives.

- Ensuring Scale, Speed and Quality in skill development environment

A conducive and effective skill environment requires:

1) Targeting skill development at all levels of the skill pyramid

2) Imparting Vocational Education in schools

3) Creating a large talent pool through Modular Employable Skills

4) Quality assured learning with effective assessment and credible certification

5) Employing technology to achieve scale

6) Public-Private partnership model for content formation, delivery, and assessment

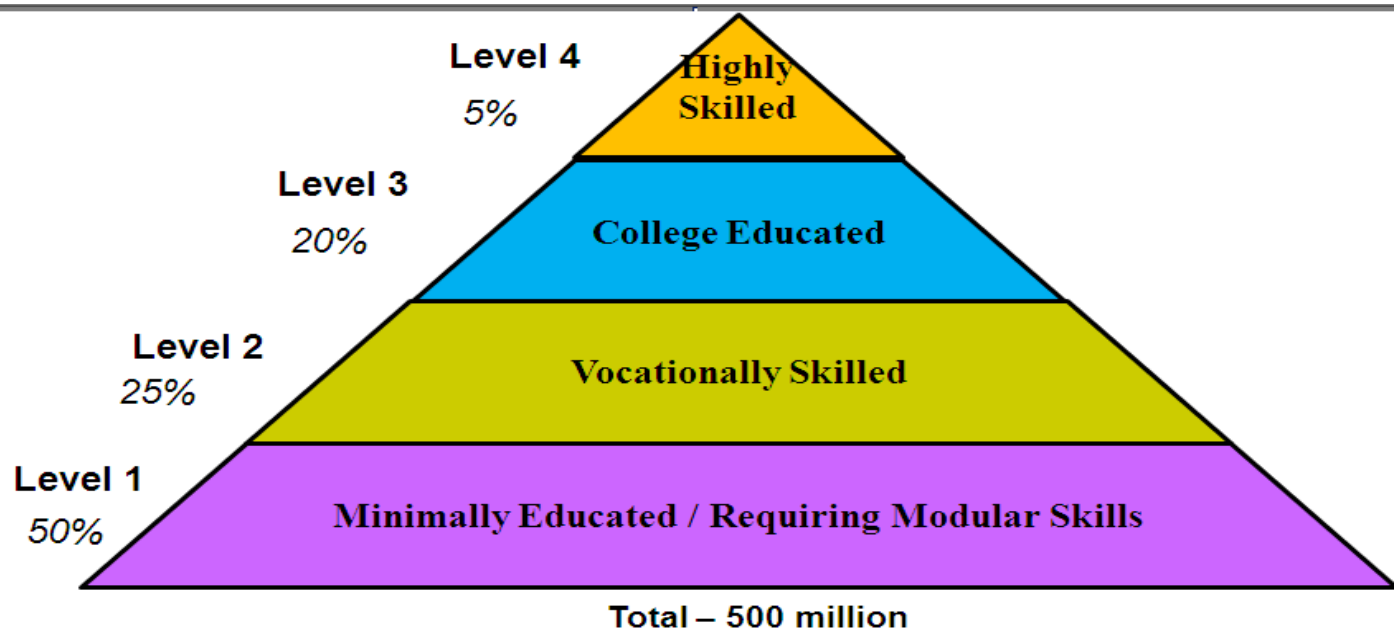

Source: IMaCS analysis 


\section{- $\quad \underline{\text { Skill Providers }}$}

There is huge shortfall of skilled trainers who can provide quality skill training under various Government skill initiatives. There is thus a need for consolidation and partnership between the Government, Public Sector units, Private sector, Educational Institutes, NGOs and Self Help Groups at the micro as well as macro level. The Government needs to expand the scope of public private partnerships.

- $\quad$ Leveraging Technology

Employing information and communication technology (ICT) as a platform for skill training as well as ensuring quality, standardization and scalability in delivery and assessment. With the recent impetus on "Digital India" by the BJP Government, access to technology and internet to all (including rural areas) doesn't seem like a far fledged dream.

- Improvement in the Financial and Regulatory framework for Growth in enterprises.

A vibrant manufacturing, especially, Small and Medium Enterprises sector can play a key role in creating jobs and high economic growth. It has the potential to provide employment for the exceptionally large labor force that is still working in agriculture. Achieving and sustaining such growth and higher employment will require a boost in industrial and services growth, spurred by SMEs. Access to financial funding is important as it is an important constraint while setting up new enterprises which will foster employment generation. The regulatory policy should reinforce the need to provide timely and adequate access to funds required for setting up and sustainably running these units. NSDC also funds private skill development initiatives.

- Focus on modular and short term courses

Due to the dynamic nature of the labour market there is a need to continuously introduce short term, need specific, training courses to fill up demand gaps in the industry.

\section{References}

1. India in Figures, MOSPI, GOI, 2015.

2. Education, Skill, Development and Labour Force, Vol III, Ministry of Labour and Employment, Labour Bureau, 2014.

3. Youth empowerment through skill development, S Ramadorai, Chairman NSDA, 2014.

4. Skill development landscape in India and implementing quality skill traning, FICCI, IMaCS, 2010.

5. Approach to the XIIth Plan,The Planning Commission.

6. Budget impact-Major fillip for skill development and social protection scheme, Business Standard, 2nd March, 2015.

7. Perspectives on skill development in Maharashtra- matching aspirations to opportunities, Delloitte, Skillcon India, March 2013. 
8. Annual Report to the People on Employment, Ministry of Labour and Employment, Government of India, 2010

9. Better Skills, Better Jobs, Better Lives, OECD, 2012

10. UNESCO GED 2010

11. India Labour Report 2007, TeamLease Services

12. Higher Education and the Labor Market in India, Pawan Agarwal

13. DISE report, 2009-10

14. Economic Survey of Maharashtra 2011-2012

15. Maharashtra Budget 2012 - 2013

16. Annual Report, 2011, Ministry of Labour and Employment

17. Vocational Education Committee Report, 2011 by Maharashtra Government

18. National Policy on Skill Development, Ministry of Labour\& Employment, Government of India

19. 2001 Census and 2011 Census, Ministry of Home Affairs

20. Economic Survey of India 2011, Ministry of Finance

21. The Challenge of Employment in India - An Informal Economy Perspective, National Commission For Enterprises inthe Unorganised Sector (NCEUS), April 2009

22. Report on National Workshop on Equivalence, Vertical Mobility of vocational courses at $10+2$ level \& Placementprospects of vocational pass-outs, 13th May 2010.

23. Skill Development in India: The Vocational Education and Training System, World Bank, 2007

24. A Global study to get India World-Ready, Building Sector Skills Body for India by Manipal City and Guilds

25. Skill Development in India - The Vocational Education and Training System, The World Bank, 2007

26. Educational statistics at a glance, Ministry of HRD, Bureau of Planning, Monitoring and Statistics, India, 2014.

27. Human Development in India- Emerging issues and policy perspectives, Report of a consultant, Institute of Human Development, sponsored by ICSSR and World Bank, 2010. 